\title{
Studies on the Quality Parameters of Some Textile Effluents and the Removal of Dye and Metal Iron Using Some Natural Bio- Adsorbents
}

\author{
Md. Masudur Rahman ${ }^{1,2}$, Ayesha Siddiqua ${ }^{1}$, Elias Khali1 ${ }^{3}$, Md. Azharul \\ Arafath $^{1}$ and S. S. Alam ${ }^{1 *}$ \\ ${ }^{I}$ Department of Chemistry \\ Shahjalal University of Science and Technology, Sylhet-3114, Bangladesh. \\ ${ }^{2}$ Basic Science Division \\ World University of Bangladesh, Dhaka-1205, Bangladesh. \\ ${ }^{3}$ Department of Textile Engineering \\ World University of Bangladesh, Dhaka-1205, Bangladesh
}

\begin{abstract}
Enormous volumes of effluent are generated at different stages of textile manufacturing, as a result of the use of copious amounts of chemicals and dyes. In this study, the analysis of various quality parameters of some textile effluents and the removal of dye and metal iron from standard solutions using some natural bioadsorbents were studied. The parameters analyzed were dissolved oxygen, chemical oxygen demand, total solid, dissolved solid, $\mathrm{pH}$, conductance, quantity of iron and dye etc. The values obtained for almost all these parameters were in the highly pollution extent. The efficiency of (a) Water hyacinth root-WHR, (b) Egg skull$E S$, (c) Sugarcane fiber-SCF and (d) Coir (coconut fiber)-CF in the removal of iron from a standard solution were $95.6 \%, 50 \%, 63.5 \%$ and $60.7 \%$ respectively for each gram of these adsorbents. In case of dye, Orange ME2RL removal efficiency found 0\%, 10.1\%, 100\%, 0\% and Black B removal efficiency found 30.9\%, 27\%, 19.9\%, 20.1\% for each gram of water hyacinth root, egg skull, sugarcane fiber and coconut fiber (coir) respectively from their standard solutions.
\end{abstract}

Keywords: Adsorption, bio-adsorbent, dye, effluent, quality parameter, spectrophotometry.

\section{Introduction}

The world's ever increasing population and her progressive adoption of an industrial- based lifestyle has inevitably led to an increased anthropogenic impact on the biosphere. Extensive pollution of fresh water is posing a serious and growing threat to sustainable development as well as protection of the environment. Human health, agricultural development, industrial development and the ecosystems are all at risk, unless water and land systems are effectively managed [1]. Best water management systems based on scientific methods and effective control of industrial waste and preventing the water resources from pollution is an important aspect. The presence of various dye and heavy metals in the water and land systems causes serious concern [2] in nature as they are non-biodegradable and may accumulate at high levels. A great number of industries including paper and pulp, printing, textile, tannery, metallurgical, electroplating, petroleum, paint, pharmaceuticals, food preserving, wood preserving, detergent use water and various types of chemicals. The textile effluents are notoriously known to contain strong color, large amount of solid, highly fluctuating $\mathrm{pH}$, Organic content and heavy metals. A common ground for these pollutants is their mode of entry into the water system. Broadly speaking, water ways are subject to entry of pollutants by: (i) direct discharge into the river-water system; (ii) run off and/or seepage with subsequent transport; (iii) reactions and transport across the air-water interface and (iv) reactions and transport across the water-sediment interface. Under all conditions, entry of the pollutants is either in dissolved or particulate form, or may be converted to these forms by chemical reactions. Colored and heavy metals containing effluents are the significant source of environmental (especially, water and soil) pollution from number of industries, particularly textile in our country. As long as the assimilation capacity of receiving water system, land, air, etc. was more than the population load, the importance of environmental degradation was not really appreciated. But there are places where rivers and other water resources are populated to the extent that they have practically no assimilation capacity due to domestic waste and trade effluents, e.g., river Buriganga at Dhaka, river Kornofuly at Chittagong etc. It is quite impossible to provide enough money with view to mitigate the problem due to these pollutions for a developing country like Bangladesh. So, for development of some cheapest and easiest methods is needed for our country. Traditional methods for dealing with the tannery wastewater consist of biological, physical and chemical method (Hamza and Hamoda, 1980; Mc Key 1980, 1984; Brower and Reed, 1987; Paprowicz and Slodczyk). Because of large 
variability of the composition of textile wastewaters most of the traditional methods are becoming inadequate. Bio-sorption utilizes the ability of biological materials to accumulate heavy metals and dye from waste streams either by metabolically mediated or purely physico-chemicals pathways of uptake [3]. A wide range of non living biomass like bark [4], lignin [5], peanut hulls [6], as well as living biomass like fungi [7-9], bacteria $[10,11]$, yeast [12,13], moss [14], aquatic plants [15] and algae [16,17] has been used as bio-sorbents. Bioadsorbents are gaining considerable importance to treat heavy metal and dye of the industrial effluents than another technology. The potential advantages of bio-adsorbents over other conventional treatment methods are: (i) low cost, (ii) high efficiency of heavy metal and colored material removal from effluents, (iii) no need to supply other chemicals, (iv) regeneration of adsorbent (v) regeneration of waste substances [18-23]. The objective of this project is to examine the use of (1) Water hyacinth root (2) Egg skull (3) Sugarcane fiber and (4) coir (coconut fiber) for the removal of dye and heavy metals from tannery effluents. If there is high activity of adsorbents to remove dye and heavy metals, these will be cheapest bio-adsorbents those are available in our country and easiest method to remove pollutant from industrial effluents.

\section{Experimental}

\subsection{Sampling}

Five samples including three effluent samples from different color processing unit of textile industries e.g. Imam Dyeing Knitting Printing \& Finishing Industries Ltd., Shyampur Industrial Area, Shyampur, Dhaka, Bangladesh were collected. A sample of dye batch used in this industry and a sample of waste water from the river Buriganga were collected also.

Table-1: Sample description

\begin{tabular}{|c|c|c|}
\hline $\begin{array}{c}\text { Sample Code } \\
\text { No. }\end{array}$ & $\begin{array}{c}\text { Name of Sample/Color } \\
\text { Processing Unit }\end{array}$ & Industry/Source \\
\hline A & Dye Batch & $\begin{array}{c}\text { Imam Dyeing Knitting Printing \& } \\
\text { Finishing Industries Ltd. }\end{array}$ \\
\hline B & $\begin{array}{c}\text { After Complete Process } \\
\text { (pink) }\end{array}$ & $\begin{array}{c}\text { Imam Dyeing Knitting Printing \& } \\
\text { Finishing Industries Ltd. }\end{array}$ \\
\hline C & $\begin{array}{c}\text { Common Drain (Mixture of } \\
\text { dyes) }\end{array}$ & Shyampur Industrial Area \\
\hline D & $\begin{array}{c}\text { After Complete Process } \\
\text { (prussian blue) }\end{array}$ & $\begin{array}{c}\text { Imam Dyeing Knitting Printing \& } \\
\text { Finishing Industries Ltd. }\end{array}$ \\
\hline E & Surface Water & Buriganga River (Shyampur ) \\
\hline
\end{tabular}

The reason for the selection this area is that it's a huge industrial area and densely populated area located at the capital city of the country. This place is geographically important and stands on the river Buriganga, one of the most significant water resources for the city.

\subsection{Techniques}

Four kinds of analytical techniques were employed throughout the present research work: 1) Titration: a) Iodometric and b) Redox; 2) Gravimetric method; 3) Spectrophotometric method and 4) Physico-chemical adsorption process by bio-adsorbents.

Table-2: Preservation technique and methods of analysis of effluent samples

\begin{tabular}{|c|c|c|c|}
\hline Parameters & Preservation Techniques & $\begin{array}{l}\text { Methods of } \\
\text { Analysis }\end{array}$ & Time \\
\hline Temperature & $\begin{array}{l}\text { No preservative; measured within } 8-10 \\
\text { hours. }\end{array}$ & Thermometer & - \\
\hline Dissolved Oxygen & $\begin{array}{l}\text { No preservative; measured within } 20- \\
24 \text { hours. }\end{array}$ & Iodometry & - \\
\hline Total solid & $\begin{array}{l}\text { No preservative; measured within 6-7 } \\
\text { days. }\end{array}$ & Gravimetric & - \\
\hline $\mathrm{pH}$ & Refrigeration at $4^{0} \mathrm{C}$; keep in dark. & $\mathrm{pH}$ Meter & $\begin{array}{l}2 \quad \text { hours/No } \\
\text { storage allowed }\end{array}$ \\
\hline Conductance & Refrigeration at $4^{0} \mathrm{C}$; keep in dark & Conductometer & 25 hours \\
\hline $\begin{array}{l}\text { Total dissol- } \\
\text { ved solid }\end{array}$ & $\begin{array}{l}\text { No preservative; measured within 3-4 } \\
\text { days. }\end{array}$ & Gravimetric & - \\
\hline $\begin{array}{l}\text { Chemical oxygen } \\
\text { demand }\end{array}$ & $\begin{array}{l}\text { Analyzed as soon as possible or add } \\
\mathrm{H}_{2} \mathrm{SO}_{4} \text { to } \mathrm{pH} \text {; Refrigeration at } 4^{0} \mathrm{C} \text {. }\end{array}$ & Redox titration & - \\
\hline Dye general & Refrigeration at $4^{0} \mathrm{C}$; keep in dark & $\begin{array}{l}\text { Spectrophotometr } \\
\mathrm{y}\end{array}$ & 15 days \\
\hline Metal general & $\begin{array}{l}\text { For dissolved metals filter } \\
\text { immediately, through a } 0.45 \mathrm{mu} \\
\text { membrane filter, add } \mathrm{HNO}_{3} \text { to } \mathrm{pH}<2 \text {. }\end{array}$ & $\begin{array}{l}\text { Spectrophotometr } \\
\mathrm{y}\end{array}$ & 20 days \\
\hline
\end{tabular}


Studies on the Quality Parameters of Some Textile Effluents and the Removal....

\subsection{Adsorption process}

At first, a washed and dried stopper bottle was taken. Then, $1 \mathrm{gm}$ of a bio-adsorbent was mixed with $100 \mathrm{~mL}$ standard dye or collected sample. Similarly, this was done in case of the adsorption of the metal, iron. After that, the bottle containing the mixture was allowed for shaking for about 6 to 8 hours.

After shaking, the mixture was allowed to settle and then the mixture was sucked and taken into a washed and dried $100 \mathrm{~mL}$ volumetric flask then taking into a test tube, the solution was allowed to centrifuge for about 20 minutes. Now, this clear solution is ready for measuring the absorbance in the UV- visible spectrophotometer. Then the concentration of the corresponding dye or metal in the sample or standard solution was determined using the corresponding calibration curve.

\subsection{Preparation of bio-adsorbents}

There are four bio-adsorbents:1) Water hyacinth root-WHR; 2) Egg skull-ES; 3) Coir (coconut fibre)CF; 4) Sugar Cane (fibre)-SCF. These were prepared as powder form by following procedure-At first, bioadsorbents were collected from natural resources, then washed well with small sizes of the bio-adsorbents, then heated in a oven with high temperature for a certain period of time and then grinded in a morter to make powder.

\section{Results \& discussion}

The surface water as well as the environment is contaminated by the disposal of different treated or untreated textile effluents. The quality parameters of investigated effluents, waste water and dye samples were analyzed using standard analytical techniques. The suitability of investigated effluents for treatment or disposal purposes was analyzed comparing with standard value.

\subsection{Results}

$\mathrm{pH}$ was measured by $\mathrm{pH}$ meter, electrical conductivity by conductometer. Total solids, total suspended solids, total dissolved solids by standard gravimetric method. Iron and dye were determined using spectrophotometric analysis. DO was determined using standard iodometric titration. COD was determined by using redox titration. The physical-chemical composition of effluent samples have been presented in table 3.1 to 3.2.The value of $\mathrm{pH}$ range were found to be $5.7-9.3$ at different color processing unit, electrical conductivity 712 to $51,400 \mu \mathrm{s} / \mathrm{cm}$, total solids 748 to $47,324 \mathrm{ppm}$, total dissolved solid 598 to $26,636 \mathrm{ppm}$, total suspended solid 28 to $21,788 \mathrm{ppm}$, temperature 21.4 to $22.0^{\circ} \mathrm{C}$. DO 0.55 to $1.90 \mathrm{ppm}$, COD 57.120 to $403.200 \mathrm{ppm}$, Iron 0.061 to $2.356 \mathrm{ppm}$, Dye 0 to $726.100 \mathrm{ppm}$.

Table-3: The various physical effluent quality parameters at different stages

\begin{tabular}{|l|c|c|c|c|c|}
\hline $\begin{array}{l}\text { Quality } \\
\text { Parameters }\end{array}$ & $\begin{array}{c}\text { Sample Code } \\
-\mathrm{A}\end{array}$ & $\begin{array}{c}\text { Sample Code } \\
-\mathrm{B}\end{array}$ & $\begin{array}{c}\text { Sample Code } \\
-\mathrm{C}\end{array}$ & $\begin{array}{c}\text { Sample Code } \\
-\mathrm{D}\end{array}$ & $\begin{array}{c}\text { Sample Code } \\
-\mathrm{E}\end{array}$ \\
\hline $\mathrm{pH}(\mathrm{at}$ 200C) & 9.3 & 9.1 & 9.3 & 5.9 & 5.7 \\
\hline $\begin{array}{l}\text { Electrical } \\
\text { conductivity } \\
(\mu \mathrm{s} / \mathrm{cm}) \text { at 250C }\end{array}$ & 50,800 & 51,400 & 3,610 & 712 & 920 \\
\hline Total solid (ppm) & 47,324 & 46,798 & 2,284 & 748 & 856 \\
\hline $\begin{array}{l}\text { Total dissolved } \\
\text { solid (ppm) }\end{array}$ & 25,536 & 26,636 & 2,106 & 598 & 828 \\
\hline $\begin{array}{l}\text { Total suspended } \\
\text { solid (ppm) }\end{array}$ & 21,788 & 20,162 & 178 & 150 & 28 \\
\hline Temperature (0C) & 21.5 & 21.4 & 21.6 & 22.0 & 21.7 \\
\hline Color & Deep red & Pink & Reddish brown & Merron & Slightly blackish \\
\hline Odor & Pleasant & Pleasant & Unpleasant & Pleasant & Unpleasant \\
\hline Turbidity & Present & Present & Present & Present & Present \\
\hline
\end{tabular}

Table-4: The concentration of various chemical effluent quality parameters at different stages

\begin{tabular}{|c|c|c|c|c|c|}
\hline Quality Parameters & $\begin{array}{c}\text { Sample } \\
\text { Code-A }\end{array}$ & $\begin{array}{c}\text { Sample } \\
\text { Code-B }\end{array}$ & $\begin{array}{c}\text { Sample } \\
\text { Code-C }\end{array}$ & $\begin{array}{c}\text { Sample } \\
\text { Code-D }\end{array}$ & $\begin{array}{c}\text { Sample } \\
\text { Code-E }\end{array}$ \\
\hline COD (ppm) & 269.567 & 249.142 & 403.200 & 60.480 & 57.120 \\
\hline DO (ppm) & 0.55 & 0.86 & 0.97 & 0.79 & 1.90 \\
\hline Iron (ppm) & 2.356 & 2.110 & 0.169 & 0.072 & 0.061 \\
\hline $\begin{array}{c}\text { Dye-Orange ME2RL } \\
(\mathrm{ppm})\end{array}$ & 292.213 & 93.893 & 0 & 5.237 & 0 \\
\hline Dye-Red RR (ppm) & 726.100 & 233.308 & 0 & 13.012 & 0 \\
\hline Dye-Black B (ppm) & 75.776 & 62.166 & 0 & 3.786 & 0 \\
\hline
\end{tabular}


Studies on the Quality Parameters of Some Textile Effluents and the Removal....

Table-5: Characterization of standard dye

\begin{tabular}{|c|c|c|c|}
\hline Characterization & Orange ME2RL & Red RR & Black B \\
\hline $\mathrm{pH}\left(\right.$ at $\left.20^{\circ} \mathrm{c}\right)$ & $4.8(1000 \mathrm{ppm})$ & $4.0(1000 \mathrm{ppm})$ & $3.7(1000 \mathrm{ppm})$ \\
\hline $\begin{array}{c}\text { Electrical } \\
\text { Conductivity } \\
(\mu \mathrm{s} / \mathrm{cm}) \text { at } 25^{\circ} \mathrm{c}\end{array}$ & $942(1000 \mathrm{ppm})$ & $552(1000 \mathrm{ppm})$ & $527(1000 \mathrm{ppm})$ \\
\hline Empirical formula & $\mathrm{C}_{10} \mathrm{H}_{8} \mathrm{O}_{7} \mathrm{~S}_{2}$ & $\mathrm{C}_{18} \mathrm{H}_{14} \mathrm{~N}_{2} \mathrm{Na}_{2} \mathrm{O}_{7} \mathrm{~S}_{2}$ & $\mathrm{C}_{29} \mathrm{H}_{24} \mathrm{~N}_{6}$ \\
\hline
\end{tabular}

Table-6: Removal of Dye using different bio-adsorbents from standard dye solutions

\begin{tabular}{|c|c|c|c|c|c|c|c|c|c|c|c|c|}
\hline \multirow[b]{2}{*}{ Sample } & \multicolumn{3}{|c|}{ Water hyacinth root } & \multicolumn{3}{|c|}{ Egg skull } & \multicolumn{3}{|c|}{ Sugarcane fiber } & \multicolumn{3}{|c|}{ Coir } \\
\hline & $\begin{array}{c}\mathrm{C}_{0} \\
\mathrm{Ppm}\end{array}$ & $\begin{array}{c}\mathrm{C} \\
\mathrm{Ppm}\end{array}$ & $\begin{array}{c}\Delta \mathrm{C} \\
\mathrm{Ppm}\end{array}$ & $\begin{array}{c}\mathrm{C}_{0} \\
\mathrm{Ppm}\end{array}$ & $\begin{array}{c}\mathrm{C} \\
\mathrm{Ppm}\end{array}$ & $\begin{array}{c}\Delta \mathrm{C} \\
\mathrm{Ppm}\end{array}$ & $\begin{array}{c}\mathrm{C}_{0} \\
\mathrm{Ppm}\end{array}$ & $\begin{array}{c}\mathrm{C} \\
\mathrm{Ppm}\end{array}$ & $\begin{array}{c}\Delta \mathrm{C} \\
\mathrm{Ppm}\end{array}$ & $\begin{array}{c}\mathrm{C}_{0} \\
\mathrm{Ppm}\end{array}$ & $\begin{array}{c}\mathrm{C} \\
\mathrm{Ppm}\end{array}$ & $\begin{array}{c}\Delta \mathrm{C} \\
\mathrm{Ppm}\end{array}$ \\
\hline $\begin{array}{l}\text { Orange } \\
\text { ME2RL }\end{array}$ & 10 & 10 & 0 & 10 & 8.99 & 1.01 & 10 & 0 & 10 & 10 & 10 & 0 \\
\hline Red RR & 10 & 10 & 0 & 10 & 10 & 0 & 10 & 10 & 0 & 10 & 10 & 0 \\
\hline Black B & 10 & 6.91 & 3.09 & 10 & 9.73 & 0.27 & 10 & 8.01 & 1.99 & 10 & 7.99 & 2.01 \\
\hline
\end{tabular}

Table-7: Removal of metal iron from standard iron solution

\begin{tabular}{|l|c|c|c|c|c|c|c|c|c|c|c|c|c|}
\hline \multirow{3}{*}{ Sample } & \multicolumn{2}{|c|}{ Water hyacinth root } & \multicolumn{4}{|c|}{ Egg skull } & \multicolumn{2}{c|}{ Sugarcane fiber } & \multicolumn{4}{c|}{ Coir } \\
\cline { 2 - 12 } & $\begin{array}{c}\mathrm{C}_{0} \\
\mathrm{ppm}\end{array}$ & $\begin{array}{c}\mathrm{C} \\
\mathrm{ppm}\end{array}$ & $\begin{array}{c}\Delta \mathrm{C} \\
\mathrm{ppm}\end{array}$ & $\begin{array}{c}\mathrm{C}_{0} \\
\mathrm{ppm}\end{array}$ & $\begin{array}{c}\mathrm{C} \\
\mathrm{ppm}\end{array}$ & $\begin{array}{c}\Delta \mathrm{C} \\
\mathrm{ppm}\end{array}$ & $\begin{array}{c}\mathrm{C}_{0} \\
\mathrm{ppm}\end{array}$ & $\begin{array}{c}\mathrm{C} \\
\mathrm{ppm}\end{array}$ & $\begin{array}{c}\Delta \mathrm{C} \\
\mathrm{ppm}\end{array}$ & $\begin{array}{c}\mathrm{C}_{0} \\
\mathrm{ppm}\end{array}$ & $\begin{array}{c}\mathrm{C} \\
\mathrm{ppm}\end{array}$ & $\begin{array}{c}\Delta \mathrm{C} \\
\mathrm{ppm}\end{array}$ \\
\hline $\begin{array}{l}\text { Standard } \\
\text { iron } \\
\text { solution }\end{array}$ & 10 & 0.44 & 9.56 & 10 & 9.50 & 0.50 & 10 & 3.65 & 6.35 & 10 & 3.93 & 6.07 \\
\hline
\end{tabular}

Here, $\mathbf{C}_{\mathbf{0}}=$ Concentration of iron before adsorption, $\mathbf{C}=$ Concentration of iron after adsorption and

$\Delta \mathbf{C}=\mathbf{C}_{\mathbf{0}}-\mathbf{C}=$ Difference in concentration of iron between that of before and after adsorption .

\subsection{Discussion}

The effluent or waste water quality parameters obtained from this collected samples were compared with the standard values recommended by (WHO, 1971). Studies on the effluent quality parameters are noted below as sample code: A-Dye Batch, B-After Complete Process (pink), C-Common Drain (mixture of dyes), DAfter Complete Process (Prussian blue) and E- Water of Buriganga (Shyampur).

\subsection{1 pH}

A critical examination of the results reveals that the $\mathrm{pH}$ of effluent samples was varied from 5.7-9.3 which indicate that all the samples are slightly acidic and highly basic in nature and the disposal of the effluents from any stage of the process to the natural water bodies will cause serious water pollution and the aquatic life will be in danger.

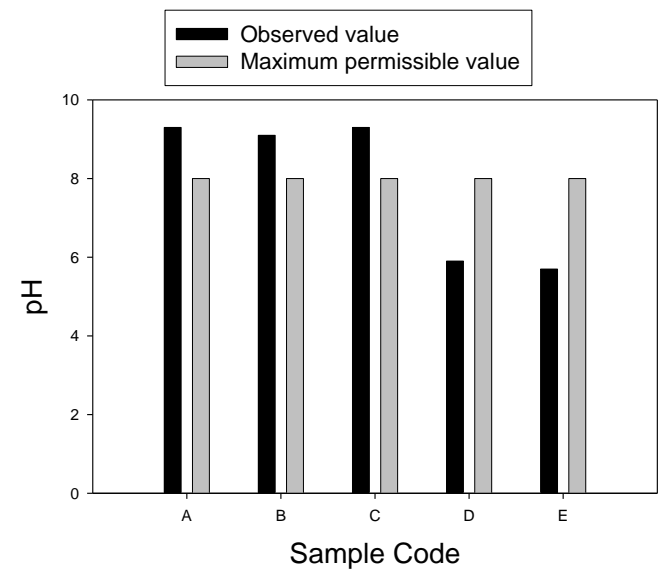

Fig.1: Bar diagram for $\mathrm{pH}$.

\subsubsection{Electrical conductivity}

The conductivity values of the collected samples varied from 712 to $51400 \mu \mathrm{s} / \mathrm{cm} \quad$ indicating high mineralization of the effluent water. Pure water would theoretically have a specific conductance (SC) value of 
zero $\mu \mathrm{s} / \mathrm{cm}$ at $25^{\circ} \mathrm{C}$. But the conductivity is not zero because some ionic species present here. According to United States Public Health Drinking Water Standard (USPH) the standard specific conductance values is $300 \mu \mathrm{s} / \mathrm{cm}$. The conductance values of the effluents exceeds safe limit.

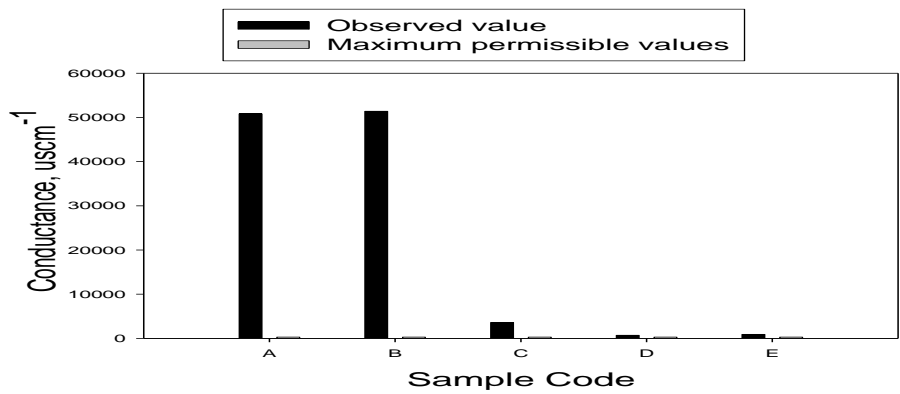

Fig.2: Bar diagram for conductance.

\subsubsection{Total solids}

The concentration of total solids in the effluent samples is found to lie within the ranges from 748 to 47324ppm. According to the United States Public Health Drinking Water Standard (USPH) the maximum permissible limit of TS is $505 \mathrm{ppm}$. The present investigation, therefore, indicates that all effluents are exceeds the safe limit of TS for drinking water.

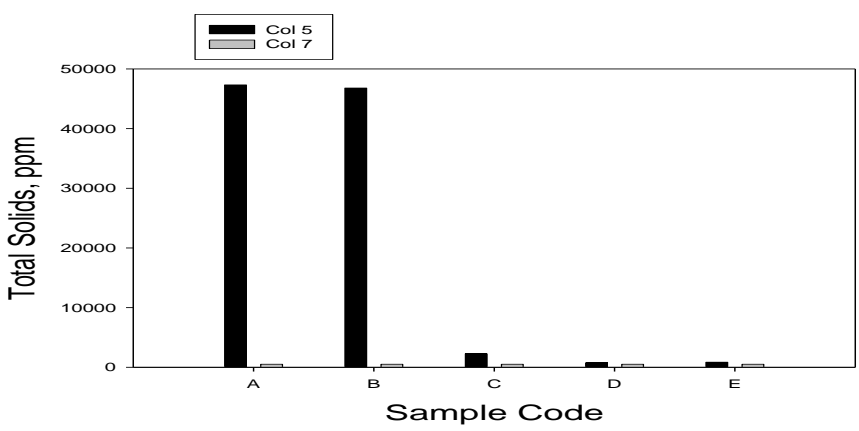

Fig.3: Bar diagram for total solids.

\subsubsection{Total dissolved solids}

The concentration of total dissolved solids in effluents was found to lie within the range 598 to 26636ppm. Water samples containing TDS less than 1000ppm are rated 'fresh water' the maximum permissible limit if DS for drinking water is 500ppm (WHO, 1971). The permissible limit of DS of standard drinking water in Bangladesh is $1000 \mathrm{ppm}$. The present investigation, therefore, indicates that all effluens exceeds the safe limit of TDS values without $\mathrm{D}$ and $\mathrm{E}$.

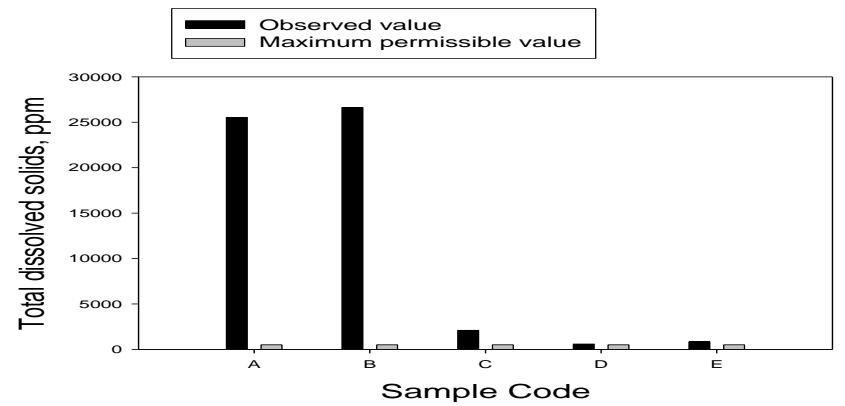

Fig.4: Bar diagram for total dissolved solids.

\subsubsection{Total suspended solids}

The concentration of total suspended solids in the following effluents was found to lie within the range of 28 to $21788 \mathrm{ppm}$. According to the United States Public Health Drinking Water Standard (USPH) the recommended level of suspended solid is $5.0 \mathrm{ppm}$. All of the samples contained higher concentration of 
suspended solid. The present investigation, therefore, indicates that the TSS values of all samples are not within safe limit for drinking and other purposes.

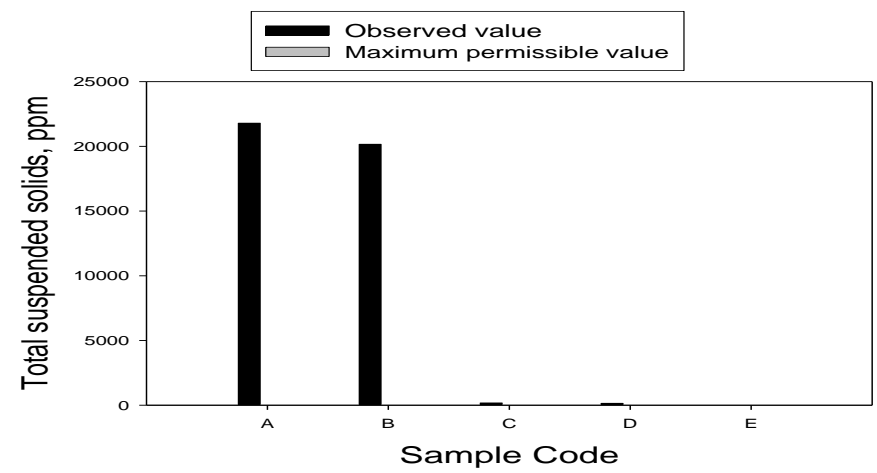

Fig.5: Bar diagram for total suspended solids.

\subsubsection{Dissolved oxygen (DO)}

Dissolved oxygen is an indicator of the depressed oxygen level and can be caused by sediment loading. The optimum DO in natural water is $4-6 \mathrm{ppm}$. Level of DO less than 4.0ppm is considered as poor in oxygen content. According to United States Public Health Drinking Water Standard (USPH) the standard value of DO in drinking water is $6 \mathrm{ppm}$. So the investigation, therefore, indicates that the DO values of the samples were poor than the expected value.

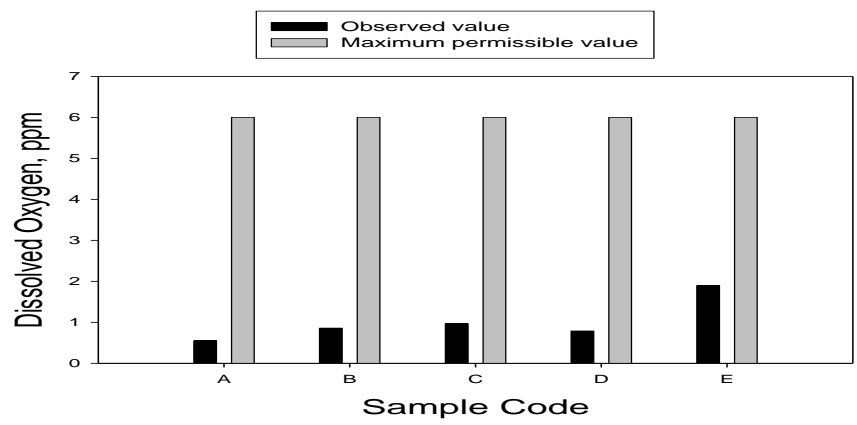

Fig.6: Bar diagram for dissolved oxygen.

\subsubsection{Chemical oxygen demand (COD)}

The COD values of the collected samples varied from $57.120 \mathrm{ppm}$ to $269.567 \mathrm{ppm}$. According to United States Public Health Drinking Water Standard (USPH) and Bangladesh standards for drinking water the recommended value is $4 \mathrm{ppm}$. The COD values of the samples were excess for drinking.

From this investigation it was found that the effluents are contaminated with organic pollutants.

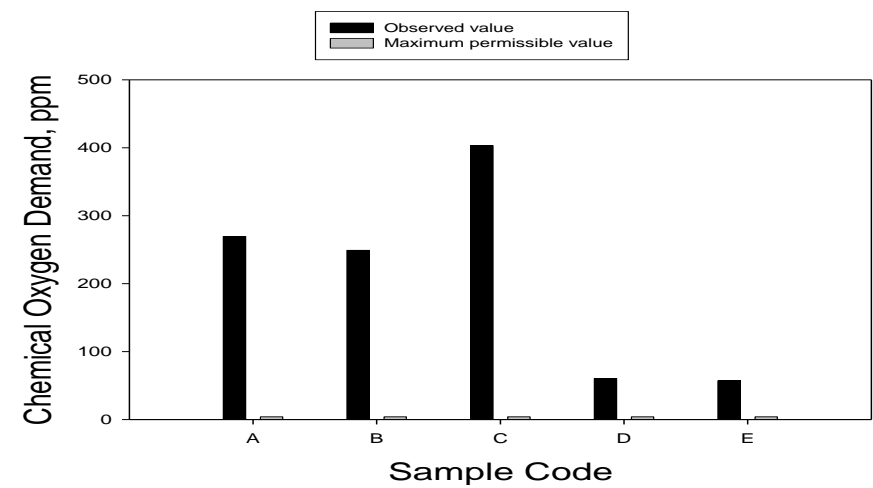

Fig.7: Bar diagram for chemical oxygen demand. 


\subsubsection{Iron}

Iron values of effluent samples were varied from 0.061 to $2.356 \mathrm{ppm}$. According to United States Public Health Drinking Water Standard (USPH) maximum permissible limit of iron for drinking purpose is $0.3 \mathrm{ppm}$. The present investigation, therefore, suggests that iron contents are high at sample -A \& B but others contain near to permissible value.

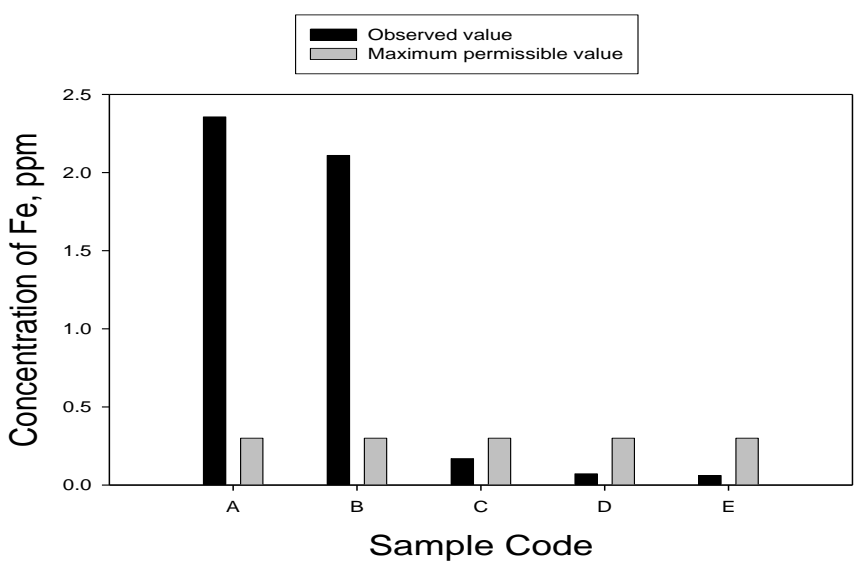

Fig.8: Bar Diagram for concentration of Fe,ppm

\subsubsection{Dyes:}

Pure water is colorless, so water containing trace amount of dye is considered to be polluted. Among the five effluent samples, sample- A, B \& D contain 292.213 ppm, 93.893 ppm and 5.237 ppm Orange ME2RL; $726.100 \mathrm{ppm}, 233.308 \mathrm{ppm}$ and $13.012 \mathrm{ppm}$ Red RR; $75.776 \mathrm{ppm}, 62.166 \mathrm{ppm}$ and $3.786 \mathrm{ppm}$ Black B respectively, i.e., highly polluted.

\subsection{Efficiency of bio-adsorbents in the removal of metal and dyes from standard solutions:}

Then the efficiency of the bio-adsorbents in case of removal of a typical metal, iron from a standard iron solution was measured. The efficiency found for water hyacinth root, egg skull, sugarcane fiber and coir were $95.6 \%, 50 \%, 63.5 \%$ and $60.7 \%$ respectively. The greater efficiency of water hyacinth root results may be due to its chemical constituents. Naturally, it has a high affinity for metals. Similar carbohydrate and amino acid distributions and tight metal binding capabilities of humic acid substituents in water hyacinth may be related to its metal binding capabilities. This may be due to the adsorbate-adsorbent electrostatic attraction. The percent removal of dye and metal iron on the adsorbents was calculated from-

$$
\% \text { removal }=\mathrm{Co}-\mathrm{C} / \mathrm{Co}^{*} 100
$$

Where, $\mathrm{Co}$ is the initial concentration and $\mathrm{C}$ is the final concentration of dye and iron in ppm.

Table-8: Percent removal of dye and metal iron by each gram of bio-adsorbents

\begin{tabular}{|c|c|c|c|c|}
\hline \multirow{2}{*}{$\begin{array}{c}\text { Name of Bio- } \\
\text { adsorbents }\end{array}$} & \multicolumn{4}{|c|}{ \% Removal } \\
\cline { 2 - 5 } & Orange ME2RL & Red RR & Black B & Iron \\
\hline 1. WHR & 0 & & & 95.6 \\
\hline 2. ES & 10.1 & 0 & 27 & 50 \\
\hline 3. SCF & 100 & 0 & 19.9 & 63.5 \\
\hline 4. CF & 0 & 0 & 20.1 & 60.7 \\
\hline
\end{tabular}

In case of dyes, Orange ME2RL removal efficiency found $0 \%, 10.1 \%, 100 \%, 0 \%$ and Black B removal efficiency found $30.9 \%, 27 \%, 19.9 \%, 20.1 \%$ for water hyacinth root, egg scull, sugarcane fibre and coconut fibre (coir) respectively. These are represented by the following bar diagram- 


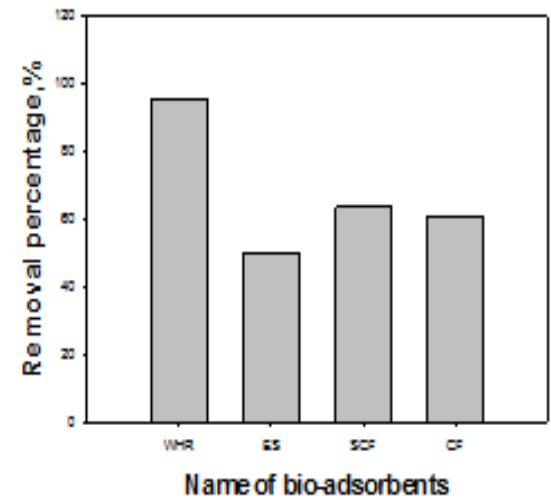

Fig.9: Eficiency of bio-adsorbents in the removal of metal,iron.

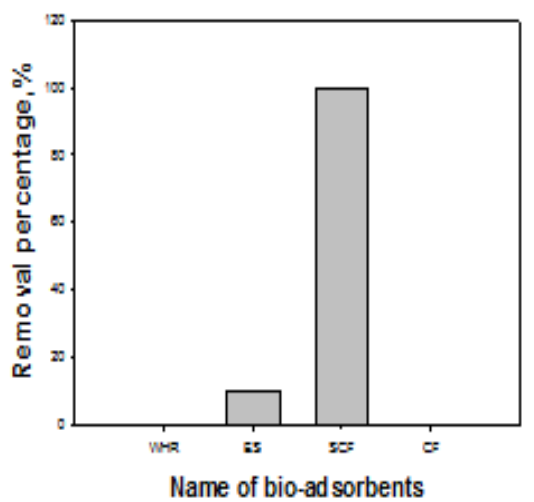

Fig.10: E ficiency of bio-adsorbents in the removal of dye, Orange ME2RL.

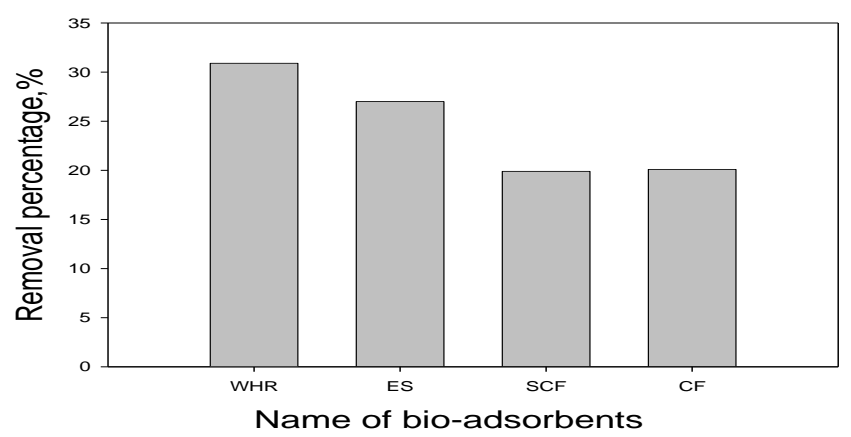

Fig.11: Efficiency of bio-adsorbents in the removal of dye,Black B.

Here, WHR= Water hyacinth root; $\mathrm{ES}=\mathrm{Egg}$ scull, $\mathrm{SCF}=$ Sugarcane fibre, $\mathrm{CF}=\mathrm{Coconut}$ fibre $($ Coir $)$.

In dyes removal except Red RR, the higher efficiency of the bio-adsorbents may be due to their chemical constituents. The chemical formula of Red RR is : $\mathrm{C}_{18} \mathrm{H}_{14} \mathrm{~N}_{2} \mathrm{Na}_{2} \mathrm{O}_{7} \mathrm{~S}_{2}$

IUPAC Name: 3-Hydroxy-4-(2,4-xylylazo)-2,7-naphthalene disulfonic acid disodium salt (M.W.480.42).

The molecules of Red RR are not adsorbed on the surface of the adsorbents may be due to the dye-adsorbent attraction is not occur here which is actually a Van der Waals attraction force. Thus Red RR removal efficiency is zero by these each gram of bio-adsorbents.

\section{Conclusion}

The various quality parameter of textile effluents and the removal of dye and metal iron using some natural bio-adsorbents e.g. water hyacinth root, egg skull, sugarcane fiber, coir (coconut fiber) were under investigation in the present research work. Both the physical and chemical parameters of the effluents were in the highly pollution extents. Most of the bio-adsorbents used were active in the removal of dye and metal iron from the corresponding standard solutions. Therefore, the removal of dyes and heavy metals present in textile effluent using these bio-adsorbents showed good results and these adsorbents could be used in industries in the treatment of textile effluent.

\section{Acknowledgements}

This research work was partially supported by the Analytical Chemistry Laboratory, Department of Chemistry, Shahjalal University of Science and Technology, Sylhet and Imam Dyeing Knitting Printing \& Finishing Industries Ltd., Shaympur, Dhaka, Bangladesh. 


\section{References}

[1]. A. Bhatia. Proceeding of the International Conference on Water and Environment, Bhopal, India, (2003) 299.

[2]. $\quad$ L.H. Keith, W.A. Telliard, Environ. Sci. Technol. 13 (1979) 416.

[3]. E. Fourest, J.C. Roux, Appl. Microbiol. Biotechnol. 37 (1992) 399.

[4]. M.M. Alves, C.G. Ceca, R.G. De Carvalho, J.M. Castanheira, M.C.S. Periera, L.A.T. Vasconcelos, Water Res. 27 (1993) 1333.

[5]. $\quad$ R.K. Srivastava, R. Tyagi, N. Pant, N. Pal, Environ. Technol. 15 (1994) 353.

[6]. K. Periasamy, K.C. Namasivayam, Ind. Eng. Chem. Res. 33 (1994) 317.

[7]. D. Lewis, R.J. Kriff, Environ. Technol. Lett. 9 (1988) 991.

[8]. K. Mohanty, Chem. Eng. 117 (2006) 71.

[9]. J.T. Matheickal, L. Iyengar, C. Venkobachar, Water Poll. Res. 26 (1991) 187

[10]. E. Fourest, C. Canal, J.C. Roux, Micobiol. Rev. 14 (1994) 332.

[11]. J.A. Scott, S.J. Palmer, Appl. Microbiol. Biotechnol. 33 (1990) 221.

[12]. J.S. Chang, R. Law, C.C. Chang, Water Res. 31 (1997) 1651

[13]. C.P. Huang, A.L. Moreheart, Water Res. 24 (1990) 433.

[14]. B. Volesky, H. May, Z. Holan, Biotechnol. Bioeng. 41 (1993) 826.

[15]. K.S. Low, C.K. Lee, Biores. Technol. 38 (1991) 1

[16]. R.K. Srivastava, S.K. Gupta, K.D.P. Nigam, P. Vasudevan, Water Res. 28 (1994) 1631.

[17]. H.B. Xue, W. Stumm, L. Stagg, Water Res. 22 (1988) 917.

[18]. Q. Yu, J.T. Matheickal, P. Kaewsarn, Water Res. 33 (1999) 1534

[19]. A.k. Chatterjee, Water Supply, Waste Disposal and Environmental Pollution Engineering, Khanna Publishers, $5^{\text {th }}$ ed $^{\mathrm{n}} .1$ (1994) 763

[20]. M.N. Rao, A.K. Datta, Waste water treatment, Oxford and IBH publishing Co. Pvt. Ltd., $2^{\text {nd }}$ ed $^{\mathrm{n}} .1$ (1987) 198.

[21]. G.N. pandy, Environmental Management, VIKAS Publishing House Pvt. Ltd., $4^{\text {th }}$ ed $^{\mathrm{n}} .1$ (2005) 1.

[22]. A Country Inventory, Hazard. Waste Management in Bangladesh, Executive Summary, (2010) XI.

[23]. J.M. Montgomery, Consulting Engineers, Inc. $2^{\text {nd }} \mathrm{ed}^{\mathrm{n}}$. (1995) 354. 